\title{
Soluble urokinase-plasminogen activator receptor (suPAR) and natural phosphorylcholine IgM antibodies in patients at clinical onset of diabetes mellitus
}

\author{
Magnus Hillman $^{1^{*}}$, Mona Landin-Olsson $^{2}$ \\ ${ }^{1}$ Department of Clinical Sciences, Lund University, Lund, Sweden; ${ }^{*}$ Corresponding Author: Magnus.Hillman@med.lu.se \\ ${ }^{2}$ Department of Medicine, Helsingborg Hospital, Helsingborg, Sweden.
}

Received 23 September 2011; revised 24 October 2011; accepted 3 November 2011.

\section{ABSTRACT}

We have studied the presence of novel inflammatory markers as soluble urokinase plasminogen activator receptor (sUPAR) and natural IgM antibodies directed against phosphorylcholine ( $\alpha \mathrm{PC}-\operatorname{lgM})$ in Swedish diabetic patients $(n=$ $164)$ and in healthy control subjects $(n=41)$. SuPAR is expressed by several types of immune cells and has been shown to be a marker of disease severity and predict mortality during infections. It has also been associated with lowgrade inflammation. High levels of $\alpha P C$-IgM have been shown to negatively associate with the risk of cardiovascular disease and vascular inflammation. This has been suggested to be more common among diabetic patients than in the background population. The patients were 15 34 years of age and were included in the diabetes incidence study in Sweden (DISS). They were all clinically diagnosed to have either T1D $(n=82)$ or T2D $(n=82)$. All subjects were matched in gender and age. Commercially available ELISA was used to detect SUPAR and $\alpha P C$-IgM. We found that suPAR levels were higher in diabetic patients ( $\left.n=164, Q_{2}=4.5 \mathrm{mg} / \mathrm{L}\right)$ compared to in healthy control subjects $\left(n=41, Q_{2}=2.7\right.$ $\mathrm{mg} / \mathrm{L} ; \boldsymbol{p}<0.0001)$, and in patients classified with T2D $\left(n=82 ; Q_{2}=4.9\right)$ compared to in patients classified with T1D $(n=82 ; p=0.0002)$. The difference between T2D and T1D was even more obvious when LADA $(n=17)$ was extracted from the T2D group. SuPAR levels did also correlate with BMI $\left(r_{s}=0.50 ; p<0.0001\right)$, C-peptide levels $\left(r_{s}=0.23 ; p<0.0001\right)$ and CRP $\left(r_{s}=0.58 ; p<\right.$ $0.0001)$. Titers of $\alpha P C-I g M$ did not significantly differ between patients and controls. This is the first study to show the difference in suPAR levels between T1D and T2D patients. The high levels of suPAR in T2D patients indicate a strong activation of the immune system and its relation to disease progression needs to be further investigated. However, our data do not support a role for $\alpha \mathrm{PC}-\lg \mathrm{M}$ in the development of diabetes.

Keywords: Diabetes Mellitus; Low-Grade Inflammation

\section{INTRODUCTION}

Type 1 diabetes (T1D) is considered to be an autoimmune disease, which results in the destruction of pancreatic islet beta cells by autoreactive $\mathrm{T}$ cells $[1,2]$. Type 2 diabetes (T2D) on the other hand is the result of decreased insulin sensitivity in peripheral tissue [3]. Even though T2D is not considered to be an autoimmune disease, some patients clinically classified with T2D appear to have autoantibodies characteristic of T1D. These patients are believed to have a slower form of T1D called latent autoimmune diabetes in adults (LADA) [4].

Mortality in cardio vascular disease (CVD) has been suggested to be higher in patients with diabetes compared to in the background population $[5,6]$. Much of the atherosclerotic plaque underlying CVD consists of oxidized lipids and low-density lipoproteins (oxLDL) [7]. These structures share epitopes like phosphorylcholine (PC) with common pathogens and has been suggested to activate leukocytes [8,9] and promote inflammation [10].

Whereas the immune response in T1D is extensively described not much is known about the role of the immune system in the development of T2D. However, several lines of evidence suggest prominent low-grade inflammation to be part of the pathophysiological mechanism [11-13].

An interesting marker of the activated immune system is the soluble receptor for urokinase plasminogen activator (suPAR) [14]. The membrane-associated form (uPAR) is a key regulator of plasminogen activation and an im- 
portant homeostatic component expressed on the surface of a wide variety of cells including several effector leukocytes [15-19] as well as non-leukocytes [20-22]. High levels of suPAR has been correlated with increased mortality risk and the severity of infectious diseases such as HIV [23], tuberculosis [24], malaria [25] and sepsis [26] but also autoimmune disease like rheumatoid arthritis [27]. Age and gender dependent variation has been reported in background suPAR levels showing a positive correlation with increased age and higher levels in women than men [28].

The biological activity of suPAR is not entirely known and it is not verified whether the molecule is active or just a result of increased cell surface release of uPAR. However, UPAR interacts with both UPA and vitronectin, the latter a structure that also interacts with integrins to regulate cellular motility [29,30] and based on the SRSRY motif in the linker region of suPAR, a chemotactic activity of the D2-D3 segment is likely to be assumed [31-33]. Recent studies have suggested an association between increased suPAR levels and risk for developing type 2 diabetes and CVD in patients above 40 years of age [34].

High titers of IgM antibodies against phosphorylcholine $(\alpha \mathrm{PC}-\mathrm{IgM})$ seem to be negatively associated with atherosclerosis and CVD while low titers in contrast relates to increased risk [35]. Characterization of these antibodies in diabetic subjects however, is currently not established and little is known about their protective role in diabetes. The protective antibodies are "natural" which means that they are believed to be germline encoded and directed against the epitopes shared with common pathogens [36]. In contrast to common antibodies, where high specificity is driven by external antigen stimuli and recombination, the function of natural antibodies are more likely to be part of the innate immunity as pattern recognition molecules [37].

The aims of this paper were:

1) To study suPAR levels in young adult patients with clinical classification of either T1D or T2D, close to clinical onset.

2) To study titers of $\alpha \mathrm{PC}$ - $\operatorname{IgM}$ antibodies in the same group of patients.

The hypothesis was that suPAR levels would be increased in autoimmune diabetes due to a massive infiltration of autoreactive $\mathrm{T}$ cells. Lower levels of $\alpha \mathrm{PC}$-IgM antibodies in diabetic subjects could indicate a less protective role by the innate immune system regarding the development of CVD and vascular inflammation.

\section{METHODS}

\subsection{Subjects}

Patients included in the study were part of the Diabe- tes Incidence Study in Sweden (DISS) and diagnosed with diabetes according to the WHO criteria [38]. All patients were 15 - 34 years old at the time of diagnosis 1998-1999. Patients clinically classified with T1D $(n=82)$ or T2D $(n=82)$ were analyzed for islet cell antibodies (ICA), glutamic acid decarboxylase antibodies (GADA), islet antigen-2 antibodies (IA-2A) as well as C-peptide to establish autoimmune diabetes and endogenous insulin production. When ICA, GADA and/or IA-2 are detected in patients with the clinical classification of T2D they are referred to as latent autoimmune diabetes in adults (LADA), a subgroup of T1D. Parameters such as plasma glucose, insulin treatment, and presence of ketonuria and/or acidosis were provided by the treating health care unit. Healthy blood donors $(n=41)$ were used as control subjects and collected between 1999 and 2000. All subjects signed a form giving informed consent. A total of 117 men and 88 women were included.

\subsection{Sample Handling}

Blood samples in EDTA tubes were collected at time of diagnosis or as close to as possible $\left(\mathrm{Q}_{2}=5\right.$ days, IQR $=18$ days). They were sent to the laboratory by ordinary mail $\left(Q_{2}=1\right.$ day; $I Q R=2$ days $)$ and plasma was separated and stored in $-70^{\circ} \mathrm{C}$ until use.

\subsection{Laboratory Assays}

Analysis of ICA, GADA and IA-2A was performed as described by Landin-Olsson [39], Falorni [40] and Gianani [41]. Analysis of C-peptide and C-reactive protein (CRP) was performed by the department of Clinical Chemistry, Lund University Hospital, Lund, Sweden. Detection limits for C-peptide and CRP was $0.01 \mathrm{nmol} / \mathrm{L}$ and $0.6 \mathrm{mg} / \mathrm{L}$ respectively. Analysis of suPAR was performed using commercial suPARnostic standard ELISA (A001, Virogates A/S, Copenhagen, Denmark) according to manufactures instructions. The detection limit of suPARnostic assay was reported to be $0.1 \mathrm{ng} / \mathrm{mL}$ and the reported precision of the kit was an intra-assay variability of $1.7 \%-4.7 \%$ and an inter-assay variation of $1.7 \%$ $5.1 \%$. Levels of natural $\alpha$ PC-IgM were measured with commercial CVDefine $^{\mathrm{TM}}$ ELISA (Athera Biotechnologies, Stockholm, Sweden) according to manufactures instructions. The detection limit of CVDefine was reported to be $0.5 \mathrm{U} / \mathrm{mL}$ and the reported precision of the kit was an intra assay variability of $4.0 \%-6.8 \%$ and an inter-assay variability of $1.1 \%-2.4 \%$. The absorbance of the samples was measured with a BioHit BP808 ELISA plate reader. The concentration of suPAR was calculated from the suPARnostic-calculator standard v1.3 (http://www.suparnostic.com/Info/toolbox.html). The titers of $\alpha$ PC-IgM were calculated from a four-parameter logistic regression standard curve using Sigma Plot v10.0 
for Windows.

\subsection{Statistics}

Normal distribution was tested for with KolmogorovSmirnov test [42]. Values are reported as median $\left(\mathrm{Q}_{2}\right)$ and followed by (min-max) in Table 1. Mann-Whitney U-test [43] or Kruskal-Wallis H-test [44] was used to test for differences in concentrations or antibody titers between groups. The Spearman rank correlation, $r_{s}$ [45] was used to test the correlation between variables. A linear multiple regression analysis was performed with suPAR as the dependent variable. Independent variables, T1D, T2D, LADA, BMI, C-peptide and CRP were added to the model. Data for type of diabetes was entered as discrete variables $(1=$ positive and $0=$ negative $)$ while other data was continuous. All statistical data was analyzed with MedCalc ${ }^{\circledR}$ for Windows v.11.5.1 (www.medcalc.org). Results were considered significant when $p<0.05$.

\section{RESULTS}

Clinical and laboratory data of interest are presented in Table 1.

\subsection{Comparison of Medians}

Median suPAR levels were significantly higher in diabetic patients $\left(\mathrm{Q}_{2}=4.5 \mathrm{ng} / \mathrm{mL}\right)$ compared to in healthy control subjects $(p<0.0001)$ (Figure 1(a)). Levels of suPAR were higher in patients with $\mathrm{T} 2 \mathrm{D}\left(\mathrm{Q}_{2}=5.3 \mathrm{ng} / \mathrm{ml}\right)$ compared to in T1D $\left(\mathrm{Q}_{2}=4.0 \mathrm{ng} / \mathrm{mL}, p=0.0001\right)$ and LADA $\left(Q_{2}=4.7 \mathrm{ng} / \mathrm{mL} ; p=0.04\right)$. SuPAR levels did not significantly differ between T1D and LADA. Females had statistically significantly higher levels of suPAR compared to in males in the group with $\mathrm{T} 1 \mathrm{D}\left(\mathrm{Q}_{2}=4.7\right.$ $\mathrm{ng} / \mathrm{mL}$ vs $3.6 \mathrm{ng} / \mathrm{mL}, p=0.008)$. However, gender was not statistically significant in the control group $\left(\mathrm{Q}_{2}=2.8\right.$ $\mathrm{ng} / \mathrm{mL}$ vs $2.6 \mathrm{ng} / \mathrm{mL} ; p=0.11)$ or in patients with $\mathrm{T} 2 \mathrm{D}$ $\left(\mathrm{Q}_{2}=5.7 \mathrm{ng} / \mathrm{mL}\right.$ vs $\left.5.1 \mathrm{ng} / \mathrm{mL}, \mathrm{p}=0.41\right)$ and LADA $\left(\mathrm{Q}_{2}\right.$ $=4.8 \mathrm{ng} / \mathrm{mL}$ vs $4.4 \mathrm{ng} / \mathrm{mL}, p=0.88$ ).

Median $\alpha$ PC-IgM did not differ between diabetic patients $\left(\mathrm{Q}_{2}=60 \mathrm{U} / \mathrm{mL}\right)$ and control subjects $\left(\mathrm{Q}_{2}=49 \mathrm{U} / \mathrm{mL}\right.$, $p=0.18)$. Neither was there any difference between the different diabetes subgroups (Figure 1(b)).

CRP was also significantly higher in diabetic patients $\left(\mathrm{Q}_{2}=2.0 \mathrm{mg} / \mathrm{L}\right)$ compared to in healthy control subjects $\left(\mathrm{Q}_{2}=0.6 \mathrm{mg} / \mathrm{L} ; p<0.0001\right)$. Also this time, the highest levels were observed in patients with $\mathrm{T} 2 \mathrm{D}\left(\mathrm{Q}_{2}=3.6\right.$ $\mathrm{mg} / \mathrm{L})$ compared to in $\mathrm{T} 1 \mathrm{D}\left(\mathrm{Q}_{2}=0.7 \mathrm{mg} / \mathrm{L}, p<0.0001\right)$. However, CRP levels were significantly different between T1D and LADA $\left(\mathrm{Q}_{2}=2.7 \mathrm{mg} / \mathrm{L}, p=0.04\right)$ but not between T2D and LADA $(p=0.19)$.

Body mass index (BMI; $\mathrm{kg} / \mathrm{m}^{2}$ ) was significantly higher in T2D patients $\left(\mathrm{Q}_{2}=33.8\right)$ compared to in T1D $\left(\mathrm{Q}_{2}=22.1 ; p<0.001\right)$ and $\operatorname{LADA}\left(\mathrm{Q}_{2}=28.6 ; p<0.01\right)$. The BMI in LADA patients was also significantly higher than in T1D $(p<0.001)$. BMI data for healthy control subjects is unfortunately missing.

Highest median C-peptide level was found among $\mathrm{T} 2 \mathrm{D}$ patients $\left(\mathrm{Q}_{2}=1.11 \mathrm{nmol} / \mathrm{L}\right)$ and followed by LADA

Table 1. Clinical and lab data of interest. Values are reported as median $\left(\mathrm{Q}_{2}\right)$ followed by (min-max). The detection limits for the ELISA are as follows, C-peptide $(0.01 \mathrm{nmol} / \mathrm{L}), \mathrm{CRP}(0.6 \mathrm{mg} / \mathrm{L}), \alpha \mathrm{PC}-\mathrm{IgM}(0.5 \mathrm{U} / \mathrm{mL}), \operatorname{suPAR}(0.1 \mathrm{ng} / \mathrm{mL}) . \mathrm{ICA}$ is an immunoflouroscence method where " 0 " represents negative and other values are positive. Higher values means stronger signal.

\begin{tabular}{|c|c|c|c|c|c|c|c|c|}
\hline & Gender & $\begin{array}{l}\text { Age } \\
\text { (yrs) }\end{array}$ & $\begin{array}{c}\text { BMI } \\
\left(\mathrm{kg} / \mathrm{m}^{2}\right)\end{array}$ & $\begin{array}{l}\text { C-peptide } \\
\text { (nmol/L) }\end{array}$ & $\begin{array}{c}\mathrm{CRP} \\
(\mathrm{mg} / \mathrm{L})\end{array}$ & $\begin{array}{c}\text { ICA } \\
\text { (JDF units) }\end{array}$ & $\begin{array}{c}\alpha \mathrm{PC}-\mathrm{IgM} \\
(\mathrm{U} / \mathrm{mL})\end{array}$ & $\begin{array}{c}\text { suPAR } \\
(\mathrm{ng} / \mathrm{mL})\end{array}$ \\
\hline \multirow{3}{*}{ Ctrl } & $\mathrm{M}(n=19)$ & $25(19-32)$ & NA & $0.47(0.18-1.12)$ & $0.6(0.6-1.4)$ & NA & $43(17-101)$ & $2.6(2.2-5.6)$ \\
\hline & $\mathrm{F}(n=22)$ & $25(19-34)$ & NA & $0.31(0.21-1.24)$ & $0.6(0.6-7.3)$ & NA & $50(17-168)$ & $2.8(2.2-4.5)$ \\
\hline & $\Sigma(n=41)$ & $25(19-34)$ & NA & $0.38(0.18-1.24)$ & $0.6(0.6-7.3)$ & NA & $49(17-168)$ & $2.7(2.2-5.6)$ \\
\hline \multirow{3}{*}{ T1D } & $\mathrm{M}(n=51)$ & $26(15-34)$ & $22.1(17.0-28.7)$ & $0.20(0.00-1.24)$ & $0.6(0.6-18.0)$ & $20(0-760)$ & $54(21-180)$ & $3.6(1.8-8.7)$ \\
\hline & $\mathrm{F}(n=31)$ & $27(18-34)$ & $22.1(17.7-36.3)$ & $0.23(0.00-0.98)$ & $1.2(0.6-29.4)$ & $4(0-100)$ & $63(11-705)$ & $4.7(2.7-6.5)$ \\
\hline & $\Sigma(n=82)$ & $26(15-34)$ & $22.1(17.0-36.3)$ & $0.20(0.00-1.24)$ & $0.7(0.6-29.4)$ & $14(0-760)$ & $55(11-705)$ & $4.0(1.8-8.7)$ \\
\hline \multirow{3}{*}{ T2D } & $\mathrm{M}(n=38)$ & $30(16-34)$ & $34.3(21.5-48.8)$ & $1.11(0.00-2.46)$ & $3.1(0.6-27.2)$ & $0(0-0)$ & $59(10-191)$ & $5.1(2.5-11.4)$ \\
\hline & $\mathrm{F}(n=27)$ & $30(20-34)$ & $32.9(22.4-49.8)$ & $1.14(0.00-3.34)$ & $5.4(0.6-24.6)$ & $0(0-0)$ & $71(9-223)$ & $5.7(2.1-8.4)$ \\
\hline & $\Sigma(n=65)$ & $30(16-34)$ & $33.8(21.5-49.8)$ & $1.11(0.00-3.34)$ & $3.6(0.6-27.2)$ & $0(0-0)$ & $60(9-223)$ & $5.3(2.1-11.4)$ \\
\hline \multirow{3}{*}{ LADA } & $M(n=09)$ & $32(19-34)$ & $25.9(20.7-46.6)$ & $0.51(0.02-0.79)$ & $3.7(0.6-16.5)$ & $30(0-100)$ & $69(32-210)$ & $4.4(1.9-6.5)$ \\
\hline & $\mathrm{F}(n=08)$ & $30(25-34)$ & $31.1(22.2-36.8)$ & $0.61(0.16-1.00)$ & $2.0(0.6-17.6)$ & $57(7-1100)$ & $62(22-180)$ & $4.8(2.0-5.5)$ \\
\hline & $\Sigma(n=17)$ & $30(19-34)$ & $28.6(20.7-46.6)$ & $0.56(0.02-1.00)$ & $2.7(0.6-17.6)$ & $45(0-1100)$ & $66(22-210)$ & $4.7(1.9-6.5)$ \\
\hline
\end{tabular}

In gender, $\mathrm{M}=$ males, $\mathrm{F}=$ females and $\Sigma=\mathrm{M}+\mathrm{F}$. 


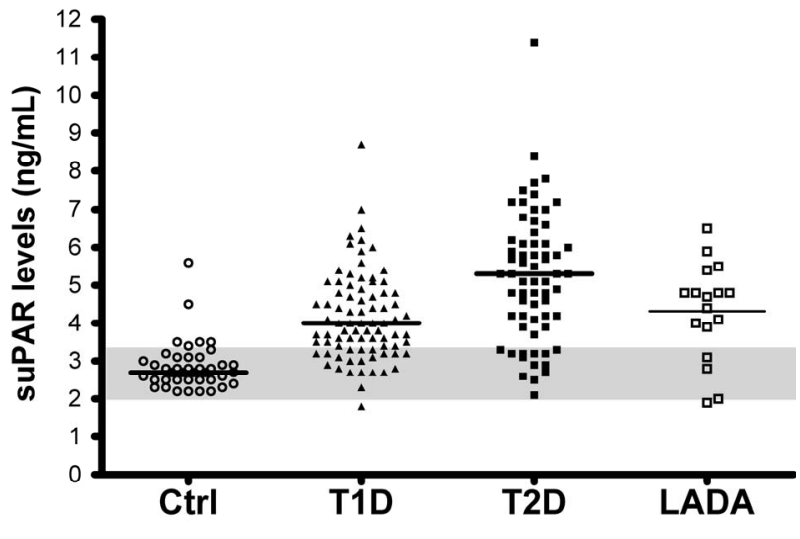

(a)

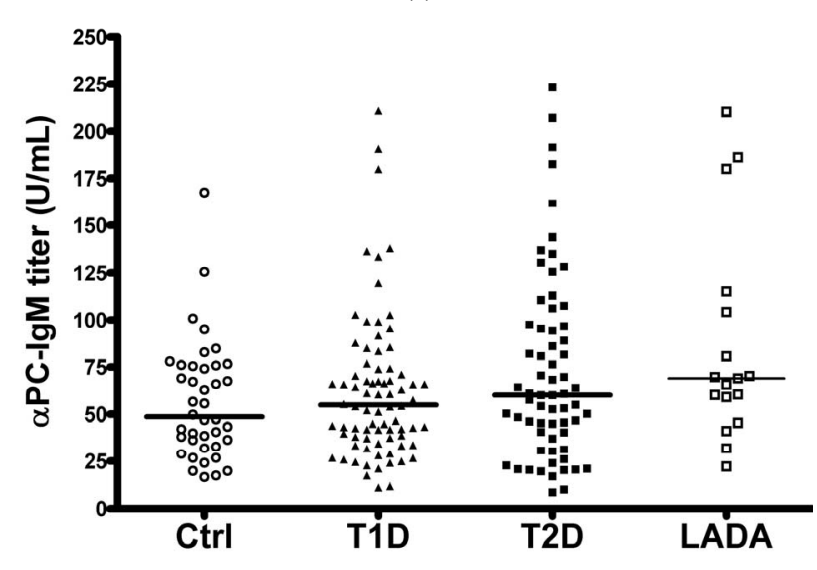

(b)

Figure 1. (a) shows plasma suPAR levels in controls and diabetic subjects at clinical onset. Kruskal-Wallis H-test indicated a statistically significant difference between controls and patients with diabetes mellitus $(p<0.0001)$. Mann-Whitney U-test indicated a significant increase of suPAR in patients with T2D compared to in T1D $(p=0.0001)$ and LADA $(p=$ $0.04)$. Levels of suPAR did not differ between T1D and LADA. Concentrations between 2.0 and $3.5 \mathrm{ng} / \mathrm{mL}$ (grey area) are considered to be "normal" values; (b) shows titers of natural IgM antibodies directed against phosphorylcholine $(\alpha \mathrm{PC}-\operatorname{IgM})$ in controls and patients. No significant differences were found between any of the groups. Two values (466 and $705 \mathrm{U} / \mathrm{mL}$ ) in the group of T1D are excluded from the graph but included in the calculation of median level. The lines in the groups of the dot plots represent the median levels. Ctrl $=$ controls, T1D = type 1 diabetes, T2D = type 2 diabetes, LADA=Latent autoimmune diabetes in adults.

$\left(\mathrm{Q}_{2}=0.56 \mathrm{nmol} / \mathrm{L}\right)$, control subjects $\left(\mathrm{Q}_{2}=0.38 \mathrm{nmol} / \mathrm{L}\right)$ and $\mathrm{T} 1 \mathrm{D}\left(\mathrm{Q}_{2}=0.20 \mathrm{nmol} / \mathrm{L}\right)$. Statistically significant differences were detected between all groups except when comparing LADA with control subjects.

\subsection{Correlation Analysis}

Correlation was observed between suPAR and CRP $\left(r_{s}\right.$ $=0.58, p<0.0001, n=205)$, suPAR and BMI $\left(r_{s}=0.51\right.$, $p<0.0001, n=164)$ as well as suPAR and C-peptide $\left(r_{s}\right.$ $=0.23, p=0.0013, n=205$ ). A slightly negative correlation was observed between suPAR and ICA in diabetic subjects $\left(r_{s}=-0.19, p=0.013\right)$ that further indicate higher levels of suPAR in T2D compared to in autoimmune diabetes. There was no correlation between suPAR levels and age $\left(r_{s}=0.08, p=0.20\right)$ in our material. Neither was there any correlation between $\alpha \mathrm{PC}$ - $\operatorname{IgM}$ and suPAR levels, BMI, C-peptide, or age. There was no difference in $\alpha$ PC-IgM titers by sex. No correlation was found between the diabetes specific autoantibodies and $\alpha \mathrm{PC}$-IgM or to the number of different autoantibodies present.

\subsection{Multiple Regression Analysis}

To test if the differences in suPAR levels between types of diabetes persisted after taking consideration to factors like BMI, CRP and C-peptide, a multiple linear regression analysis was performed. According to this model, BMI was the only variable that significantly affected the suPAR levels $(p<0.0001)$ (Table 2).

\section{DISCUSSION}

We found that suPAR concentrations were signifycantly higher in patients with onset of diabetes mellitus in the $15-34$ years age group compared to in age and gender matched non-diabetic control subjects. Increased levels of suPAR have been observed in other autoimmune disorders such as rheumatoid arthritis [27] and it is reasonable to assume that it is the result of an activated immune response similar to infectious disease. Hence, we were expecting to find high suPAR levels in patients with T1D since this condition is characterized by substantial infiltration of autoreactive $\mathrm{T}$ cells in pancreatic islets. Slightly increased suPAR levels in low-grade inflammation have also been suggested but the highly significant increase in T2D compared to an autoimmune disorder like T1D was unexpected.

The strength of the study is that we used a rather young population that has not been extensively studied before in respect to suPAR and $\alpha \mathrm{PC}-\mathrm{IgM}$. The patients are also included in a nationwide study and followed on an annual basis. Thus, it should be possible to follow up these patients with respect to treatment and diabetes specific complications, especially in relation to suPAR levels. To our knowledge, this is the first time a comparison of suPAR between T1D and T2D has been performed. A limitation of the study is that the number of patients and controls were restricted due to assay expenses. Even though the number of subjects was adequate for a pilot study it is desirable to repeat the study with a larger number of subjects in the future. Another limitation is the lack 
Table 2. Results from the multiple regression analysis. SuPAR is the dependent variable and type of diabetes, BMI, C-peptide and $\mathrm{CRP}$ as independent variables. The $\mathrm{R}^{2}$-adjusted was 0.27 in this model.

\begin{tabular}{lccc}
\hline & $\boldsymbol{\beta}$-Coefficient & CI $_{\mathbf{9 5}}$ & $\boldsymbol{p}$ \\
\hline T1D & 0.47 & $(-1.37)$ to 2.31 & 0.62 \\
T2D & 0.47 & $(-1.43)$ to 2.37 & 0.63 \\
LADA & -0.12 & $(-2.06)$ to 1.82 & 0.90 \\
BMI & 0.10 & 0.05 to 0.15 & $<0.0001$ \\
C-peptide & -0.14 & $(-0.63)$ to 0.34 & 0.55 \\
CRP & 0.04 & $(-0.01)$ to 0.09 & 0.14 \\
\hline
\end{tabular}

of basic clinical data such as BMI and ICA among healthy controls. However, antibodies directed against GAD and IA-2 was not found among the controls and thus ICA is not expected in this group.

Increased suPAR levels have recently been suggested to be part of the T2D spectra [34] although the patients in our study are considerably younger. We found a strong correlation between plasma suPAR levels and plasma CRP in agreement with other studies [28,46]. BMI and C-peptide were also higher in the group with T2D and correlated well with suPAR. In fact, BMI was the only independent variable that could explain the variation of suPAR among diabetic subjects (Table 2). Yet, since we lack data of BMI in control subjects, this observation must be interpreted with cautiousness. BMI is normally higher in patients with T2D so an increase of any marker in T2D would also correlate with BMI. Therefore, the relation to suPAR in this study is difficult to establish with current data. The suPAR and BMI correlation has not been identified as significant in nondiabetic populations $[28,34]$ while CRP appears to be related to both BMI and plasma lipids. CRP is thus suggested to be a good marker of both metabolic inflammation and microbial infection while suPAR is more related to overall immune activation [47]. From one aspect, our data also supports this observation since the differences between T1D and LADA are evident when it comes to BMI $(p<0.0001)$ and CRP $(p=0.04)$ but not suPAR ( $p$ $=0.34)$. Thus LADA, which is the more obese group among autoimmune diabetic subjects, also show higher CRP but similar suPAR levels, maybe reflecting a similar immune activation.

Even though patients with T2D and LADA were a few years older than patients with T1D and controls subjects, there were no correlation between suPAR and age. One explanation could be that all subjects in our study are younger adults (15 - $34 \mathrm{yr}$ of age) and thus the less distinct age dependent suPAR variation. Another explanation could be that the impact from diabetes on suPAR levels is so much stronger than age specific contribution in our study. However, we could see a statistically sig- nificant gender difference for patients with T1D, promoting high suPAR levels in women, but not for patients with T2D or LADA. Again, the impact from T2D on suPAR levels might be so strong that gender dependent variation fades. The group with LADA is probably too small to recognize any natural variation in suPAR levels. Neither could we find a significant difference in the control group, which is also too small.

Activated macrophages in adipose tissue are of major importance when it comes to the development of obesity related inflammation. They are likely to be the source of the proinflammatory cytokines observed in obesity, contributing to insulin resistance as well as T2D [11]. Whether they might be the source of suPAR or not in T2D cannot be concluded by our data but raises a significant question for future research. Elevated suPAR levels have also been related to Insulin resistance [48], which possibly could explain the strong correlation to C-peptide in our study.

High levels of natural antibodies directed against phosphorylcholine $(\alpha \mathrm{PC}$-IgM) have been associated with a decreased risk of cardiovascular disease [35]. This led us to believe that diabetic patients with increased risk of CVD could have lower levels of $\alpha$ PC-IgM. However, this was not confirmed in our material of young adult subjects. Since the levels of natural antibodies should be independent of age, complications in diabetes are probably unrelated to the $\alpha \mathrm{PC}-\operatorname{IgM}$ levels.

The origin of inflammation in our T2D patients is not easily identified. The strong correlation between suPAR and CRP suggests an ongoing immune response in both T1D and T2D. High suPAR levels in T2D patients further signify the role of the immune system in this metabolic disorder. Based on higher suPAR levels, we suggest that the immune mediated response is even more severe in T2D compared to in T1D. Even though T2D is not considered to be an autoimmune disorder the innate immune response is systemic and more extensive, leading to inflammation, in contrast to the organ specific adaptive autoimmune response in T1D.

The prognostic value of suPAR has been shown several times in severe infections [23-26] where it predicts mortality during quite short follow-up time. Whether this is also true for diabetic subjects is currently not known. Another exciting thought is that suPAR levels in diabetic subjects perhaps have a predictive value for future development of diabetes related complications. Studies with these approaches need to be addressed in order to understand the role of suPAR in diabetes.

\section{CONCLUSIONS}

In conclusion, this is the first study to show suPAR levels in young adult patients with diabetes. The findings 
indicate a strong activation of the immune system in diabetes regardless of type. The role of suPAR in illness progression of diabetes needs to be further studied. We found no evidence that $\alpha$-PC IgM contributes to the level of inflammation in diabetes and suggest that the pathobiology of diabetes is independent of these titers in young adult diabetic subjects.

\section{ACKNOWLEDGEMENTS}

Members of the Diabetes incidence study in Sweden are Hans Arnquist (Linköping), Jan Bolinder (Stockholm), Per-Ola Carlsson (Uppsala), Mona Landin-Olsson (Lund), Olov Rolandsson (Umeå), Soffia Gudbjörnsdottir (Göteborg), Lennarth Nyström (Umeå) and Jan Östman (Stockholm). Thanks to Mrs Birgitte Ekholm for excellent technical assistance.

The study was supported by a grant from the Crafoord Foundation, Lund, Sweden to Magnus Hillman and Swedish Medical Research Council and The Swedish Diabetes Foundation to Mona Landin-Olsson.

Data from this study was presented by Dr Hillman at the 2nd international suPAR symposium in Copenhagen, March, 8th 2011.

\section{REFERENCES}

[1] McKenzie, M.D., Dudek, N.L., Mariana, L., Chong, M.M., Trapani, J.A., Kay, T.W. and Thomas, H.E. (2006) Perforin and Fas induced by IFN $\gamma$ and TNF $\alpha$ mediate beta cell death by OT-I CTL. International Immunolgy, 18, 837-846. doi:10.1093/intimm/dx1020

[2] Campbell, P.D., Estella, E., Dudek, N.L., Jhala, G., Thomas, H.E., Kay, T.W. and Mannering, S.I. (2008) Cytotoxic T-lymphocyte-mediated killing of human pancreatic islet cells in vitro. Human Immunology, 69, 543-551. doi:10.1016/j.humimm.2008.06.008

[3] Schinner, S., Scherbaum, W.A., Bornstein, S.R. and Barthel, A. (2005) Molecular mechanisms of insulin resistance. Diabetic Medicine, 22, 674-682. doi:10.1111/j.1464-5491.2005.01566.x

[4] Zimmet, P.Z., Tuomi, T., Mackay, I.R., Rowley, M.J., Knowles, W., Cohen, M. and Lang, D.A. (1994) Latent autoimmune diabetes mellitus in adults (LADA): The role of antibodies to glutamic acid decarboxylase in diagnosis and prediction of insulin dependency. Diabetic Medicine, 11, 299-303.

doi:10.1111/j.1464-5491.1994.tb00275.x

[5] Haffner, S.M., Lehto, S., Ronnemaa, T., Pyorala, K. and Laakso, M. (1998) Mortality from coronary heart disease in subjects with type 2 diabetes and in nondiabetic subjects with and without prior myocardial infarction. New England Journal of Medicine, 339, 229-234.

doi:10.1056/NEJMoa052187

[6] Nathan, D.M., Cleary, P.A., Backlund, J.Y., Genuth, S.M., Lachin, J.M., Orchard, T.J., Raskin, P. and Zinman, B. (2005) Intensive diabetes treatment and cardiovascular disease in patients with type 1 diabetes. New England Journal of Medicine, 353, 2643-2653 doi:10.1056/NEJMoa052187

[7] Binder, C.J., Chang, M.K., Shaw, P.X., Miller, Y.I., Hart- vigsen, K., Dewan, A. and Witztum, J.L. (2002) Innate and acquired immunity in atherogenesis. Nature Medicine, 8, 1218-1226 doi:10.1038/nm1102-1218

[8] Frostegard, J., Wu, R., Giscombe, R., Holm, G., Lefvert, A.K. and Nilsson, J. (1992) Induction of T-cell activation by oxidized low density lipoprotein. Arteriosclerosis, Thrombosis, and Vascular Biology, 12, 461-467. doi:10.1161/01.ATV.12.4.461

[9] Quinn, M.T., Parthasarathy, S. and Steinberg, D. (1998) Lysophosphatidylcholine: A chemotactic factor for human monocytes and its potential role in atherogenesis. Proceedings of the National Academy of Sciences of the USA, 85, 2805-2809. doi:10.1073/pnas.85.8.2805

[10] Huang, Y.H., Schafer-Elinder, L., Wu, R., Claesson, H.E. and Frostegard, J. (1999) Lysophosphatidylcholine (LPC) induces proinflammatory cytokines by a platelet-activating factor (PAF) receptor-dependent mechanism. Clinical and Experimental Immunology, 116, 326-331. doi:10.1046/j.1365-2249.1999.00871.x

[11] Heilbronn, L.K. and Campbell, L.V. (2008) Adipose tissue macrophages, low grade inflammation and insulin resistance in human obesity. Current Pharmaceutical Design, 14, 1225-1230. doi:10.2174/138161208784246153

[12] Duncan, B.B., Schmidt, M.I., Pankow, J.S., Ballantyne, C.M., Couper, D., Vigo, A., Hoogeveen, R., Folsom, A.R. and Heiss, G. (2003) Low-grade systemic inflammation and the development of type 2 diabetes: The atherosclerosis risk in communities study. Diabetes, 52, 1799-1805. doi:10.2337/diabetes.52.7.1799

[13] Herder, C., Illig, T., Rathmann, W., Martin, S., Haastert, B., Muller-Scholze, S., Holle, R., Thorand, B., Koenig, W., Wichmann, H.E. and Kolb, H. (2005) Inflammation and type 2 diabetes: Results from KORA Augsburg. Gesundheitswesen, 67, 115-121. doi:10.1055/s-2005-858252

[14] Ploug, M., Ronne, E., Behrendt, N., Jensen, A.L., Blasi, F. and Dano, K. (1991) Cellular receptor for urokinase plasminogen activator. Carboxyl-terminal processing and membrane anchoring by glycosyl-phosphatidylinositol. The Journal of Biological Chemistry, 266, 1926-1933.

[15] Krishnan, R., Kremen, M., Hu, J.H., Emery, I. and Farris, S.D., Slezicki, K.I., Chu, T., Du, L., Dichek, H.L. and Dichek, D.A. (2009) Level of macrophage uPA expression is an important determinant of atherosclerotic lesion growth in Apoe ${ }^{-/-}$mice. Arteriosclerosis, Thrombosis, and Vascular Biology, 29, 1737-1744. doi:10.1161/ATVBAHA.109.195529

[16] May, A.E., Schmidt, R., Kanse, S.M., Chavakis, T., Stephens, R.W., Schomig, A., Preissner, K.T. and Neumann, F.-J. (2002) Urokinase receptor surface expression regulates monocyte adhesion in acute myocardial infarction. Blood, 100, 3611-3617. doi:10.1182/blood-2002-03-0778

[17] Park, Y.-J., Liu, G., Tsuruta, Y., Lorne, E. and Abraham, E. (2009) Participation of the urokinase receptor in neutrophil efferocytosis. Blood, 114, 860-870. doi:10.1182/blood-2008-12-193524

[18] Ferland, C., Guilbert, M., Davoine, F., Flamand, N., Chakir, J. and Laviolette, M. (20001) Eotaxin promotes eosinophil transmigration via the activation of the plasminogen-plasmin system. Journal of Leukocyte Biology, 
69, $772-778$.

[19] Mondino, A. and Blasi, F. (2004) uPA and uPAR in fibrinolysis, immunity and pathology. Trends in Immunology, 25, 450-455. doi:10.1016/j.it.2004.06.004

[20] Schaefer, B.M., Stark, H.J., Fusenig, N.E., Todd, R.F. and Kramer, M.D. (1995) Differential expression of urokinase-type plasminogen activator (uPA), its receptor (uPA$\mathrm{R}$ ), and inhibitor type-2 (PAI-2) during differentiation of keratinocytes in an organotypic coculture system. Experimental Cell Research, 220, 415-423. doi:10.1006/excr.1995.1333

[21] Bernstein, A.M., Twining, S.S., Warejcka, D.J., Tall, E. and Masur, S.K. (2007) Urokinase receptor cleavage: A crucial step in fibroblast-to-myofibroblast differentiation. Molecular Biology of the Cell, 18, 2716-2727. doi:10.1091/mbc.E06-10-0912

[22] Mandriota, S.J., Seghezzi, G., Vassalli, J.-D., Ferrara, N., Wasi, S., Mazzieri, R., Mignatti, P. and Pepper, M.S. (1995) Vascular endothelial growth factor increases urokinase receptor expression in vascular endothelial cells. The Journal of Biological Chemistry, 270, 9709-9716. doi:10.1074/jbc.270.17.9709

[23] Ostrowski, S.R., Ullum, H., Goka, B.Q., Hoyer-Hansen, G., Obeng-Adjei, G., Pedersen, B.K., Akanmori, B.D. and Kurtzhals, J.A. (2005) Plasma concentrations of soluble urokinase-type plasminogen activator receptor are increased in patients with malaria and are associated with a poor clinical or a fatal outcome. The Journal of Infectious Diseases, 191, 1331-1341. doi:10.1086/428854

[24] Eugen-Olsen, J., Gustafson, P., Sidenius, N., Fischer, T.K., Parner, J., Aaby, P., Gomes, V.F. and Lisse, I. (2002) The serum level of soluble urokinase receptor is elevated in tuberculosis patients and predicts mortality during treatment: A community study from Guinea-Bissau. The International Journal of Tuberculosis and Lung Disease, 6, 686-692.

[25] Perch, M., Kofoed, P., Fischer, T.K., Co, F., Rombo, L., Aaby, P. and Eugen-Olsen, J. (2004) Serum levels of soluble urokinase plasminogen activator receptor is associated with parasitemia in children with acute Plasmodium falciparum malaria infection. Parasite Immunology, 26, 207-211. doi:10.1111/j.0141-9838.2004.00695.x

[26] Wittenhagen, P., Kronborg, G., Weis, N., Nielsen, H., Obel, N., Pedersen, S.S. and Eugen-Olsen, J. (2004) The plasma level of soluble urokinase receptor is elevated in patients with Streptococcus pneumoniae bacteraemia and predicts mortality. Clinical Microbiology and Infection, 10, 409-415. doi:10.1111/j.1469-0691.2004.00850.x

[27] Slot, O., Brunner, N., Locht, H., Oxholm, P. and Stephens, R.W. (1999) Soluble urokinase plasminogen activator receptor in plasma of patients with inflammatory rheumatic disorders: Increased concentrations in rheumatoid arthritis. Annals of the Rheumatic Diseases, 58, 488-492. doi:10.1136/ard.58.8.488

[28] Sehestedt, T., Lyngbæk, S., Eugen-Olsen, J., Jeppesen, J., Andersen, O., Hansen, T.W., Linneberg, A., Jørgensen, T., Haugaard, S.B. and Olsen, M.H. (2011) Soluble urokinase plasminogen activator receptor is associated with subclinical organ damage and cardiovascular events. Atherosclerosis, 216, 237-243. doi:10.1016/j.atherosclerosis.2011.01.049

[29] Wei, Y., Lukashev, M., Simon, D.I., Bodary, S.C., Ro- senberg, S., Doyle, M.V. and Chapman, H.A. (1996) Regulation of integrin function by the urokinase receptor. Science, 273, 1551-1555. doi:10.1126/science.273.5281.1551

[30] Wei, Y., Czekay, R.-P., Robillard, L., Kugler, M.C., Zhang, F., Kim, K.K., Xiong, J.-P., Humphries, M.J. and Chapman, H.A. (2005) Regulation of $\alpha 5 \beta 1$ integrin conformation and function by urokinase receptor binding. The Journal of cell Biology, 168, 501-511. doi:10.1083/jcb.200404112

[31] Pliyev, B.K. (2009) Activated human neutrophils rapidly release the chemotactically active D2D3 form of the urokinase-type plasminogen activator receptor (uPAR/CD87). Molecular and Cellular Biochemistry, 321, 111-122. doi:10.1007/s11010-008-9925-Z

[32] Høyer-Hansen, G., Ploug, M., Behrendt, N., Rønne, E. and Danø, K. (1997) Cell-surface acceleration of urokinase-catalyzed receptor cleavage. European Journal of Biochemistry, 243, 21-26. doi:10.1111/j.1432-1033.1997.0021a.x

[33] Høyer-Hansen, G., Rønne, E., Solberg, H., Behrendt, N., Ploug, M., Lund, L.R., Ellis, V. and Danø, K. (1992) Urokinase plasminogen activator cleaves its cell surface receptor releasing the ligand-binding domain. The Journal of Biological Chemistry, 267, 18224-18229.

[34] Eugen-Olsen, J., Andersen, O., Linneberg, A., Ladelund, S., Hansen, T.W., Langkilde, A., Petersen, J., Pielak, T., Møller, L.N., Jeppesen, J., Lyngbaek, S., Fenger, M., Olsen, M.H., Hildebrandt, P.R., Borch-Johnsen, K., Jørgensen, T. and Haugaard, S.B. (2010) Circulating soluble urokinase plasminogen activator receptor predicts cancer, cardiovascular disease, diabetes and mortality in the general population. Journal of Internal Medicine, 268, 296-308. doi:10.1111/j.1365-2796.2010.02252.x

[35] De Faire, U. and Frostegård, J. (2009) Natural antibodies against phosphorylcholine in cardiovascular disease. $A n-$ nals of the New York Academy of Sciences, 1173, 292-300. doi:10.1111/j.1749-6632.2009.04748.x

[36] Avrameas S. (1991) Natural autoantibodies: From "horror autotoxicus" to "gnothi seauton". Immunology Today, 12, 154-159. doi:10.1016/S0167-5699(05)80045-3

[37] Harnett, W. and Harnett, M.M. (1999) Phosphorylcholine: Friend or foe of the immune system? Immunology Today, 20, 125-129. doi:10.1016/S0167-5699(98)01419-4

[38] American Diabetes Association (1992) Clinical practice recommendations. 1991-1992. Diabetes Care, 15, 1-80.

[39] Landin-Olsson, M. (1990) Precision of the islet-cell antibody assay depends on the pancreas. Journal of Clinical Laboratory Analysis, 4, 289-294. doi: $10.1002 /$ jcla. 1860040410

[40] Falorni, A., Ortqvist, E., Persson, B. and Lernmark, A. (1995) Radioimmunoassays for glutamic acid decarboxylase (GAD65) and GAD65 autoantibodies using 35S or $3 \mathrm{H}$ recombinant human ligands. Journal of Immunological Methods, 186, 89-99. doi:10.1016/0022-1759(95)00139-2

[41] Gianani, R., Rabin, D.U., Verge, C.F., Yu, L., Babu, S.R., Pietropaolo, M. and Eisenbarth, G.S. (1995) ICA512 autoantibody radioassay. Diabetes, 44, 1340-1344. doi:10.2337/diabetes.44.11.1340

[42] Chakravarti, I.M., Laha, R.G. and Roy, J. (1967) Handbook of methods of applied statistics. John Wiley \& Sons, 
Ltd., New York.

[43] Mann, H.B. and Whitney, D.R. (1947) On a test of whether one of two random variables is stochastically larger than the other. Annals of Mathematical Statistics, 18, 50-60 doi:10.1214/aoms/1177730491

[44] Kruskal, W.H. and Wallis, W.A. (1952) Use of ranks in one-criterion variance analysis. Journal of the American statistical Association, 47, 583-621. doi: $10.2307 / 2280779$

[45] Spearman, C. (2010) The proof and measurement of association between two things. International Journal of Epicemiology, 39, 1137-1150. doi:10.1093/ije/dyq191

[46] Koch, A., Voigt, S., Kruschinski, C., Sanson, E., Duckers,
H., Horn, A., Yagmur, E., Zimmermann, H., Trautwein, C. and Tacke, F. (2011) Circulating soluble urokinase plasminogen activator receptor is stably elevated during the first week of treatment in the intensive care unit and predicts mortality in critically ill patients. Critical Care, 15, R63. doi:10.1186/cc10037

[47] Eugen-Olsen, J. (2011) suPAR - A future risk marker. Journal of Internal Medicine, 270, 29-31. doi:10.1111/j.1365-2796.2011.02372.x

[48] Andersen, O., Eugen-Olsen, J., Kofoed, K., Iversen, J. and Haugaard, S.B. (2008) suPAR associates to glucose metabolic aberration during glucose stimulation in HIV-infected patients on HAART. Journal of Infection, 57, 55-63. doi:10.1016/j.jinf.2008.01.014 